\title{
The relationship of vocabulary and reading comprehension in the writing skills descriptive text reviewed gender
}

\author{
Silvana Nurdiani ${ }^{1}$, Syahrul. $\mathbf{R}^{2}$, Abdurahman ${ }^{3}$ \\ ${ }^{123}$ Universitas Negeri Padang, Padang - Indonesia, (yusianatira@gmail.com)
}

\begin{abstract}
This research to test the hypothesis in Contribution of vocabulary and reading comprehension on the writing skills description text reviewed gender, in a sample of 105 (52 males and 53 females) Junior high school students selected at random sampling. The data these research data were collected with multiple choice tests and performance tests, of this analyzed using regression technique Statistical analysis revealed that the contribution of vocabulary knowledge and reading comprehension in the main and interaction effects. Results of correlational analysis suggest that vocabulary and reading comprehension related significantly to the writing skills description text.
\end{abstract}

Keywords: contribution, vocabulary, reading comprehension, and writing skill description

\section{Introduction}

This study is based on some findings on the skills of writing description text. First, students do not understand the description text so students can't distinguish the type of text description with the other text. Secondly, the low vocabulary mastery that the students have so that to understand the text of the students find it difficult. Third, students also have low reading ability. This has ever been discussed in the daily article Kompas (29/2/2012) interest in reading Indonesian society is still low recorded a book read about 80.000 population of Indonesia. Further Tribun News (19/09/2013) states interest in reading citizens of Indonesia is very low and apprehensive. This is evidenced by the results of the national index which states that Indonesia Read index is only 0.01 . The average reading index of developed countries ranges from 0.45 to 0.62 .

This study is based on some findings on the skills of writing description text. First, students do not understand the description text so students can't distinguish the type of text description with the other text. Secondly, the low vocabulary mastery that the students have so that to understand the text of the students find it difficult. Third, students also have low reading ability. This has ever been discussed in the daily article Kompas (29/2/2012) interest in reading Indonesian society is still low recorded a book read about 80.000 population of Indonesia. Further Tribun News (19/09/2013) states interest in reading citizens of Indonesia is very low and apprehensive. This is evidenced by the results of the national index which states that Indonesia Read index is only 0.01 . The average reading index of developed countries ranges from 0.45 to 0.62 . 
Meanwhile Thahar (2008: 52), express writing is an intellectual activity. An intellectual is characterized by his ability to express his way of thinking through writing with the perfect language medium. A person is not an intellectual, it is difficult to formulate his or her own way of thinking reflected in the way he speaks or writes. Semi (2009: 3) also says a good writer is a good reader. People may not have the ability to write if they do not have the ability to listen and read well. Because writing consisting of information, emotions and thoughts is a product or a result of listening and reading. In other words the activity and the ability to listen and read is the basic capital for writing activities. Tarigan (2011: 69) states that there are several ways that teachers can enrich the vocabulary of students that is to introduce synonyms of words, antonyms, paraphrases, words of the same nature; introducing an inclusion that includes prefixes, inserts, and suffixes; and guessing or guessing the word in context based on the text. All that can be realized by teachers with creative power.

Meanwhile Hajimohamma in a research in 2017 said that learners should conceptualize their reading text comprehension such as text writers in order to understand the text. Then they concentrate on applying lexical, syntactic, and semantic and the background knowledge they have for processing knowledge can write down the ideas they have, so that the resulting writing becomes qualified. Priyatni (2014: 72) also points out that, the description text is a text that exposes something so that the reader as if the listener, sees, hears the item described is categorized as a description text. The Description text is used to describe the specific characteristics that humans, animals or objects have specifically exemplified: My pet, my father, My house, Simmon my dog, and others.

Meanwhile Hajimohamma in a research in 2017 said that learners should conceptualize their reading text comprehension such as text writers in order to understand the text. Then they concentrate on applying lexical, syntactic, and semantic and the background knowledge they have for processing knowledge can write down the ideas they have, so that the resulting writing becomes qualified. Priyatni (2014: 72) also points out that, the description text is a text that exposes something so that the reader as if the listener, sees, hears the item described is categorized as a description text. The Description text is used to describe the specific characteristics that humans, animals or objects have specifically exemplified: My pet, my father, My house, Simmon my dog, and others.

Based on the above explanation it is necessary to conduct research on the Relationship Ability to Read Understanding and Mastery of Vocabulary on Text Writing Skills Description of Student Class VII SMP Negeri Se-Padang Pariaman District Viewed from Gender Perspective.

\section{Method}

The method used in this research is quantitative method. According to Arikunto (2008: 10), quantitative research is, research using data that is processed using numbers, ranging from data collection, and appearance results. Data processing techniques in this study are simple correlation and regression, as well as multiple correlation and regression.

The population and sample of this study are all students of class VII of SMP Negeri in Padang Pariaman District which has used the curriculum 2013 which amounted to 976 . The sample in this study amounted to 105 people consisting of 52 men, and 53 women. with purpotional random sampling sampling technique. The instruments used in this study are objective test and performance test. All the tests used in the study have passed the validation of both the expert validator, as well as the results of the test questions. data collection of this research conducted on November 17 until December 24, 2016. Data collection techniques used in this study using tests that use instruments that have been valid. Before the research hypothesis is tested in advance test prerequisite data analysis. Such as normality test, homogeneity test, indentpendency test and linearity test. Followed by test of research hypothesis. 


\section{Results and Discussion}

The results of this research will explain three subjects. First, the Relationship of Reading Ability Understanding of Writing Skills Text Description in terms of Gender Perspective. Second, Vocabulary Relationship of Writing Skill Text Description Description Viewed from Perpsketif Gender. Third, the Relationship of Reading Ability of Understanding and Mastery of Vocabulary Together on Writing Textual Descriptions Description Viewed from a Gender Perspective.

Relationship of Reading Ability Understanding to Writing Skills Text Description Reviewed from a Gender Perspective

The result of statistical calculation for the relationship of reading comprehension ability to the writing skill of description skill from the perspective of gender shows that the correlation coefficient (ry1) $=0,328$. With the price $\mathrm{F}=0.001<0.05$. at $\mathrm{N}=105$. This means that there is a correlation of reading comprehension skills to the skills of writing descriptive text from a gender perspective. This means that the ability to read comprehension has a significant relationship and make a meaningful contribution to the writing skills of description text of 32.8\% in Grade VII Students of SMP N SePadang Pariaman District viewed from a gender perspective.

Based on these achievements can be seen that there is a significant relationship between the ability to read comprehension with the skills to write text description of students of class VII SMP Padang Pariaman District. This means the better the ability of students in reading comprehension will be more skilled students in writing text description. This can be illustrated from the average reading skill of students on each indicator. The lowest indicator and the most need to be trained in reading comprehension is the indicator of the field of passengers 72,19 . While the indicator reads the most understandable comprehension of the students is to find the main idea $(81,40)$, it is also seen in the students' writing skills when expressing the idea for the content indicator in writing the description text that the student memeperoleh average $(80,48)$. Followed by an indicator determining the structure of the text (80.56) it also has a significant relationship with the skills of writing description text for organizational indicators (82.14). For indicators of questions based on texts obtain 79.75. The indicator summarizes the reading 72.48 .

\section{Relationship of Vocabulary Mastery to Writing Skills Text Description Reviewed from Gender Perspective}

The result of statistical calculation for the relationship of vocabulary mastery to the skill of writing the description text from the perspective of gender, shows that the correlation efficiency (ry2) $=0,397$. With the price $\mathrm{F}=$ at alpha $0,000<0,05$ with $\mathrm{N}=105$. This means that there is a correlation of vocabulary mastery of the skills of writing descriptive text from a gender perspective. Vocabulary mastery has a significant relationship and make a significant contribution to the skill of writing a description text of 39.7\% in Grade VII Students of Junior High School N Kabupaten Padang Pariaman viewed from a gender perspective.

The result of descriptive analysis shows that vocabulary exclusion belongs to good category of score $(81,17)$ ideal. While seen in each indicator of research, indicator find words that have opposite meaning (antonym) have the lowest average value that is 79,99 . While the indicators find the meaning of the text in context to get the average value of 84,10 . Then for the indicator to determine the word that has the similarity of meaning (synonym) of the seventh grade students of Junior High School in Padang Pariaman District obtained a score of 85.74 .

For that in the mastery of vocabulary teachers in schools need to improve students' ability in finding words that have the opposite meaning. Because of the three indicators used to find words that have the opposite meaning. To improve the vocabulary, many things can be done by teachers in learning. Starting from memorizing vocabulary activities, doing reading activities, often doing listening activities, as well as inventory words either general or any special word. Tarigan (2011: 69) 
states that there are several ways that teachers can enrich the vocabulary of the students that is introducing synonyms of words, antonyms, paraphrases, similarly grounded words; introducing an inclusion that includes prefixes, inserts, and suffixes; and guessing or guessing the word in context based on the text. All that can be realized by teachers with creative power.

Relationship Reading Ability Understanding and Mastering Vocabulary Together to Writing Skills Text Description Viewed from Gender Perspective

Based on data analysis and reading comprehension ability and vocabulary mastery of class VII students of SMP N Padang Pariaman Regency viewed from gender perspective show that correlation efficiency $($ ry 12$)=0,440$. With the price $\mathrm{F}=$ at alpha $0.000<0.05$. This means that vocabulary mastery has a significant relationship and makes a meaningful contribution to the writing skill of descriptive text of $44 \%$ in Grade VII Students of SMP N Padang Pariaman District viewed from a gender perspective. Ability to read comprehension and mastery of vocabulary as well as skills Writing Text description can be seen in the following table.

The discussion will always connect to the introduction by way of the research questions or hypotheses you posed and the literature you reviewed, but it does not simply repeat or rearrange the introduction; the discussion should always explain how your study has moved the reader's understanding of the research problem forward from where you left them at the end of the introduction.

Table 1. Statistical Test Results Data Description Reading Ability of Understanding, Vocabulary Mastery and Description Text Writing Skills Viewed from Gender Perspective

\section{Research variable}

Statistics

\begin{tabular}{ccc}
\hline Vocabulary & Reading & Writing Skills Text \\
Mastery (X1) & Comprehension (X2) & Description (Y)
\end{tabular}

L

P $\quad$ L

$\mathbf{P}$

$\mathbf{P}$

L

$\mathbf{P}$

\begin{tabular}{ccccccc}
\hline Mean & 74 & 82 & 81 & 80 & 81 & 76 \\
\hline Minimal & 68 & 65 & 60 & 63 & 50 & 62 \\
\hline Maksimal & 98 & 100 & 95 & 98 & 87 & 90 \\
\hline
\end{tabular}

Viewed from the perspective of gender, the ability to read the understanding of male students of grade VII in Padang Pariaman District is 81 , meanwhile female students 80 , it is known that in reading the understanding of male students is better than the ability to read the understanding of female students, in advance that female students tend to prefer feminine and imaginative reading materials. While reading material for reading comprehension is more factual. Therefore it is necessary to approach and treat the female students to be able to understand the factual reading, in order to improve the skills of writing the text description. It is known that the average vocabulary mastery of male class VII students in Padang Pariaman District is 74, meanwhile female students 82, it is known 
that female students have better vocabulary mastery than male students. therefore students mastery mastery of male students need to be done to be able to improve his skills in writing text description.

Meanwhile, when viewed from a gender perspective, the writing skills capability of men is also better than the writing skill of female students description. The skill of writing the descriptive text of male students of grade VII in Pariaman District is 81, meanwhile female students 76, based on the above table it is known that male students have better writing text description skills than female students. Haris (1998: 59) points out that boys prefer to read factual information, seeking only certain information that is desired rather than reading from beginning to end. Then Bugel (1996: 16-27) reveals that women have a feminine and imaginative reading interest. Instead men like masculine and scientific reading topics. In accordance with previous theoretical studies because the text description is a factual text it does not rule out the possibility that female students more difficulty in exposing his ideas into the form of writing description, compared with male students. Thus to be able to both have good skills both male and female students need to improve the ability to read understanding and mastery of vocabulary to be able to improve the skills of writing text description.

\section{Conclusions}

Based on data analysis and discussion can be concluded three things. First. Ability Reading comprehension contributes to the skill of writing the text description of the seventh grade students of SMP N Padang Pariaman District by $32.8 \%$. This means that the ability to read comprehension makes a significant contribution to the skill of writing a description text. the better the ability to read students' understanding the better the skills of writing the description of the student's text. Second, vocabulary mastery contributes to the writing skills of the description text of $39.7 \%$.

This means that mastery of vocabulary contributes to the improvement of writing skills of description text in schools. The better the vocabulary mastery of the students and the better the teacher in training and multiplying the mastery of vocabulary students will be better the students also in writing the text description. Third, Judging from the perspective of gender, the ability to read comprehension and vocabulary mastery of the seventh grade students of Junior High School in Padang Pariaman District together contributed significantly to the improvement of descriptive writing skills by $44 \%$. This means the better the ability to read comprehension and vocabulary mastery of students the better the skills of writing text description of students of class VII of SMP N Padang Pariaman District.

\section{Acknowledgments}

In the implementation of research and preparation of this article, the authors get a lot of help and guidance from various parties. On this occasion the author would like to thank sincerely to: Prof. Dr. Syahrul R, M.Pd As Advisor I and Dr. Abdurahman, M.Pd As Advisor II, and Mr and Mrs Examiner: Prof. Dr. Atmazaki, M.Pd, Prof. Dr. Harris Tahar, M.Pd, and Dr. Yahya Tambunan, M.Pd.

\section{References}

Abdurahman dan Elya Ratna. (2003). "Evaluasi Pembelajaran Bahasa dan Sastra Indonesia". Padang: UNP Press.

Arikunto, Suharsimi. (2006). Prosedur Penelitian. Jakarta: Rineka Cipta

Bugel, Karin and Bram P. Buunk. (1996)." Sex Differences in Foreign Languages Teks Comprehension". The Modern Langage Journal vol. 80 (1).

Hariss, Vee. (1998). “Making Boys Make Progress". Language Laerning Journal no. 18. 
Hajimohammadi, Reza. (2017). The Relationship between Iranian ESP Learners' Translation Ability and Resilience in Reading Comprehension (The Journal) International Journal of Education \& Literacy Studies Vol. 5 No. 2; April 2017 ISSN 2202-9478.

KOMPAS.com. (2012)."Minat baca Indonesia Masih rendah" (artikel edisi Rabu 29/02 2012)

Priyatni, Endah. T. (2014). Disain Pembelajaran Bahasa Indonesia dalam kurikulum 2013. Jakarta: Bumi Aksara.

Semi, M. Atar. (2009). Menulis Efektif. Padang: UNP Press.

Thahar, Harris Effendi. (2008). Menulis Kreatif Panduan Bagi Pemula. Padang: UNP Press

Tarigan, Hendy Guntur. (2011). Pengajaran Kosa Kata. Bandung:Angkasa. 